\title{
Biogenesis of «fusty» defect in virgin olive oils
}

\author{
By F. Angerosa, B. Lanza and V. Marsilio \\ Istituto Sperimentale per la Elaiotecnica, Contrada Fonte Umano n. 37, \\ 65013-Cittá S. Angelo, Pescara, Italy
}

\section{RESUMEN}

\section{Biogénesis del atrojado en el aceite de oliva virgen}

La biogénesis del atrojado ha sido estudiada química y microbiológicamente en aceitunas amontonadas durante diferentes períodos de tiempo; además ha sido evaluado el aceite procedente de la elaboración de dichos frutos. La percepción de atrojado era percibida por el panel de catadores sólo después de cuatro días de almacenamiento de las aceitunas. La determinación cuanti-cualitativa de los compuestos aromáticos del aceite resultante se ha relacionado con los microorganismos implicados en la degradación de los frutos. Se han encontrado algunos compuestos volátiles como el 2- y 3metil butan-1-al y sus correspondientes alcoholes, el ácido propiónico, el ácido 2-metil propiónico y el 3-metil butanoico. Al mismo tiempo, ha sido observado el fuerte desarrollo de especies del género Clostridium y, en menor proporción, de Pseudomonas. Asimismo, durante el almacenamiento se produjo un ablandamiento de los frutos a causa de la acción de las enzimas pectolíticas de microorganismos de rápido crecimiento, pertenecientes al género Enterobactery a mohos.

PALABRAS-CLAVE: Aceite de oliva virgen - Atrojado Compuestos volátiles - Microorganismo.

\section{SUMMARY}

\section{Biogenesis of «fusty» defect in virgin olive oils}

The biogenesis of "fusty» defect was studied by chemical and microbial analyses on olives stored in piles for different times and their resulting oils. The fusty defect was perceived by tasters after four days of storage. The quali-quantitative composition of oil volatile fraction was a very suitable way to emphasize metabolites produced by microorganisms involved during the fruit storage. Some volatile compounds, such as 2- and 3- methyl butan-1-al, their corresponding alcohols and propionic acid, 2 methyl propionic acid and 3-methyl butanoic acid, were produced. At he same time, it was observed a dramatic development of Clostridium sp. and, in a lower proportion, of Pseudomonas sp. Furthermore, during the storage the evident softening of fruits has to be attributed to microorganisms in rapid growth belonging to Enterobactersp. and moulds, that have in its enzymatic store pectinolytic enzymes.

KEY-WORDS: Fusty defect - Microorganism - Virgin olive oil - Volatile compounds.

\section{INTRODUCTION}

Virgin olive oil flavour is tight connected with the quali-quantitative composition of volatile compounds, which determine the whole of olfactory perceptions, and that of phenolic substances responsible of taste attributes.

Agronomic factors, such as ripening degree of fruits, cultivar, climate, soil, and technological systems of extraction modify aromatic notes of virgen olive oils (1-10). Among these parameters, time and storage conditions are of great importance, since most of organoleptic defects arise during the olive storage before their extraction (11-13): as a consequence of presence of defects and in relation to their intensities, oils are declassed to lower commercial classes.

Olive harvest occurs in a few months of the year and often the poor size of processing plants makes impossible their extraction immediately after the harvest. In these conditions the storage of notable quantities of fruits for times more or less long is generally used. Preservation, even if made in ideal conditions, i.e. in thin layer in fully-airy rooms and at the temperature of a usual winter season, is the cause of $30-40 \%$ flavour flattening after only 15 days (11). Neverthless, the reduced area reserved to olive storage in relation to fruits quantities obliges to put them into juta sacks or in piles of notable thickness leading to either a deterioration of fruits, with a noteworthy warming of bulk, and to the appearance of characteristic «fusty» defect in resulting oils.

Gutierrez et al. (12) studied volatile compounds of oils produced by fruits after three months of storage in piles. They evidenced the increase of contents of alcohols, of which some branched, aldehydes arising from the oxidation of unsatured fatty acids, and short chain fatty acids, as acetic, propionic, 2-methyl propionic, butanoic, 2-methyl butanoic, pentanoic and hexanoic acids. Neverthless, since oils showed at the same time many defects in comparable intensities, as fusty, musty, muddy, vinegary and winey, they did not correlate any compound with the fusty defect. 
The results of further researches on the influence of storage in piles on the oil flavour (13) showed that the fusty defect, perceived by tasters after four days of olive storage, could be related to high contents of volatile alcohols, mainly 2-methyl butan-1-ol; at the same time, oils exhibited a flavour drastic fall because of considerable decrease of 2-hexen-1-al and phenolic compounds.

The great spreading of this kind of olive storage and the few data on fusty defect biogenesis present in literature led us to acquire a profound knowledge of this feature, in order to be able to suggest expedients for its prevention. The aim of this work was i) to determine metabolites correlated with the fusty defect, ii) to identify microorganisms responsible of the production of these compounds, and iii) to study the evolution of both metabolites and microorganisms during the storage.

\section{EXPERIMENTAL}

Sampling: Fruits of olive trees (Olea europaea L. cv. Nebbio), grown in Abruzzo (Italy), were picked on December 1994. Fruits were put into a jute sack having a capacity of about $70 \mathrm{~kg}$ and stored at the room temperature approximately of $18^{\circ} \mathrm{C}$; in these conditions the warming of the olive bulk occurred and therefore four samplings, from the middle sack zone, at regular intervals of two days (2, 4, 6 and 8 days), were carried out for oil extraction and microbial analysis. Moreover, it would be specified that olives of last sample were undergone an large invasion of moulds.

Oil extraction: $5 \mathrm{~kg}$ of fruits just harvested and those from cited samplings were deleafed, washed and crushed with a hammer mill; the resulting pastes were cold kneaded for about $30 \mathrm{~min}$ and then the oils were extracted for emergence with basket centrifuge.

Oil sensory analysis and analytical determinations:

- Organoleptic characteristic were evaluated by eight tasters of the Istituto Sperimentale per la Elaiotecnica (Pescara, Italy) Panel, according to EC reg. n. 2568 (14);

- HRGC of volatile compounds extracted with nitrogen at $37^{\circ} \mathrm{C}$, adsorbed on active charcoal, eluted by diethyl ether and separated on Carbowax 20M capillary column in accordance with the method described in a previous work (12).

\section{Microbial analyses:}

Pre-isolation. At each sampling, $50 \mathrm{~g}$ of fruits, corresponding to about 25 olives, were random picked up for the isolation of microorganisms from the olive surface. The sample was suspended in $100 \mathrm{ml}$ of sterile physiological solution; after stirring in ultrasonic bath for $5 \mathrm{~min}$, serial dilutions of the suspension were prepared and inoculated in the suitable growth media.
Isolation. For the isolation and microbial growth the following media were used:

- Bacto Plate Count Agar (Difco), for total microbial count at $30^{\circ} \mathrm{C}$;

- M.R.S. Agar (Oxoid), for lactic acid bacteria;

- Pseudomonas Agar Base+CFC Supplement (Oxoid), for Pseudomonas sp.;

- Pseudomonas Agar Base + CN Supplement (Oxoid), for P. aeruginosa;

- Iron Sulphite Agar (Oxoid), for clostridia;

- MacConkey Agar n.ㅇ 3 (Oxoid), for coliforms;

- Sabouraud Chloramphenicol Agar (Liofilchem), for moulds;

- Henneberg III, for acetic acid bacteria;

- Malt Extract Agar (Liofilchem), for yeasts;

- M17 (Biolife), for lactic streptococci.

Identification. The isolates were identified according to the Bergey's Manual of Determinative Bacteriology (15). The biochemical characterization of strains was carried out using the following systems:

- API 20 E (bioMerieux), for enteric bacteria;

- API 20 NE (bioMerieux), for non-enteric Gramnegative bacteria;

- API 50 CHL (bioMerieux), for lactic acid bacteria;

- Rapid ID 32A (bioMerieux), for anaerobic microorganisms;

- ID 32 C (bioMerieux), for yeasts.

Data were elaborated by a computer-assisted software (APILAB Plux, bioMerieux), which interprets the biochemical profiles obtained with the identification strips, evaluating the degree of reliability of the species assigned.

Scanning Electron Microscopy. Tissue blocks from equatorial zone of olive fruit were fixed in $2.5 \%$ glutaraldehyde in $0.1 \mathrm{M}$ phosphate buffer $\mathrm{pH} 7.2$ (Sorensen buffer) for $8 \mathrm{hr}$ at $0-4^{\circ} \mathrm{C}$. After 3 washings with the same buffer, the samples were dehydrated in an alcohol series $(30,50,70,80,90,100$ and $100 \%$ of ethanol for 15 min each), dried, by means of $\mathrm{CO}_{2}$, in a Critical Point Dryer (Balzers CPD 030), mounted on aluminium stubs and coated with gold (20 nm thick) in a Sputter Coater (Balzers SCD 050). The samples were observed at 10,15 and $20 \mathrm{kV}$ with a Scanning Electron Microscope (Philips SEM XL 20) equipped with a Polaroid camera.

\section{RESULTS AND DISCUSSION}

Fig. 1 showed the microbic colonization of olive tissues observed by Scanning Electron Microscope (SEM). As a consequence of the autolysis of organic material, the epicarp lost its ability of antimicrobic barrier. This promoted, in the storage in sacks of olives, the invasion of tissues from microorganisms present in environment, which accelerate the complete fruit rot, since suitable conditions of temperature and high humidity help their development. The olive degradation 
is primerly due to microbial attack; in fact the autolysis, occurring when fruits are stored in ideal conditions, caused only a progressive flattening of resulting oil flavour without any distortion (11).

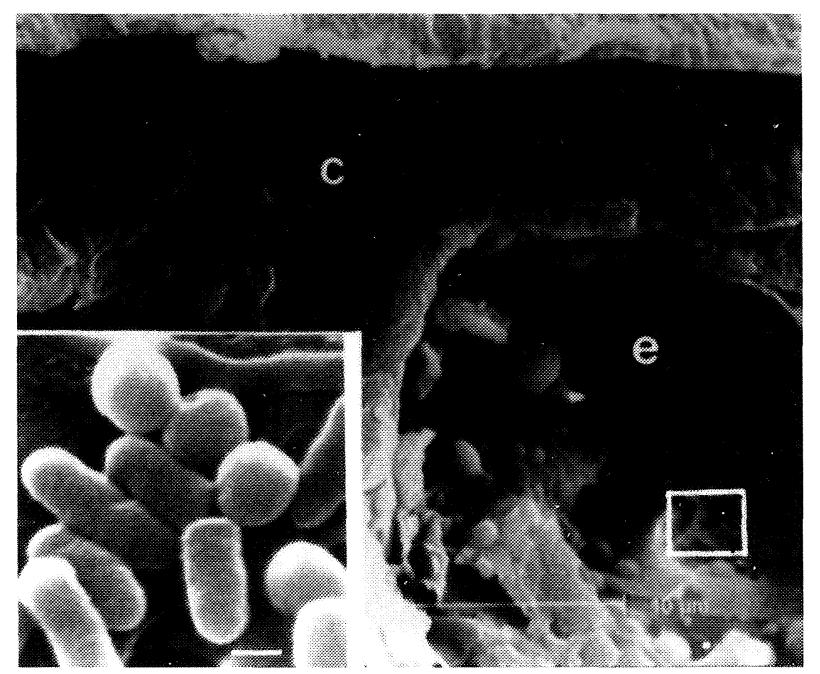

Figure 1

Microbic colonization of the olive tissues. $c=$ cuticle layer; $\mathrm{e}=$ epidermal cell. Bar in the square $=0.5 \mu \mathrm{m}$

Table I gave the evaluations of oil samples obtained from fruits at different times of storage and some characteristics of flavours. The analysis of the profile sheets evidenced that the "fusty» defect was perceived by tasters after only four days of preservation; the defect was more intensely detected in the subsequent samplings. Moreover, the panelists found the presence of very accentuated sensations fo "vinegary" and «musty» in oils extracted from last two samplings (6 and 8 storage days). Furthemore the Panel test scores and fruity intensities progressively decreased during all storage period. These findings were according to those published by other authors (13).

Table I

\section{Organoleptic evaluations and flavour} characteristics

\begin{tabular}{lccc}
\hline Storage days & Panel test & Fruity intensity & Main defects \\
\hline 0 & $7.2 \pm 0.3$ & $2.8 \pm 0.3$ & absent \\
2 & $6.6 \pm 0.3$ & $2.3 \pm 0.2$ & absent \\
4 & $6.2 \pm 0.3$ & $2.0 \pm 0.0$ & fusty \\
6 & $5.0 \pm 0.3$ & $1.3 \pm 0.4$ & fusty, vinegary, musty \\
8 & $4.1 \pm 0.4$ & $0.9 \pm 0.2$ & fusty, vinegary, musty \\
\hline
\end{tabular}

Each value is the mean \pm SE $x$ t of eight tasters (t represents Student's $t$ for $95 \%$ confidence limits).
The profile of aromatic volatile compounds was significantly modified as from the starting days of olive storage (Fig. 2); besides, it was confirmed by organoleptic evaluations. In fact, aromagrams of oils obtained from fruits inmmediately processed after harvest showed considerable peaks in relation to sixcarbon compounds, aldehydes, alcohols and esters, arising from very well known lipoxygenase pathway $(9,16,17)$. On the contrary, in the same gas chromatogram only insignificant quantities of compounds, arising from common cellular pathways, were present and therefore the increases of these latter had to be attributed to the intervention of exogenous agents.
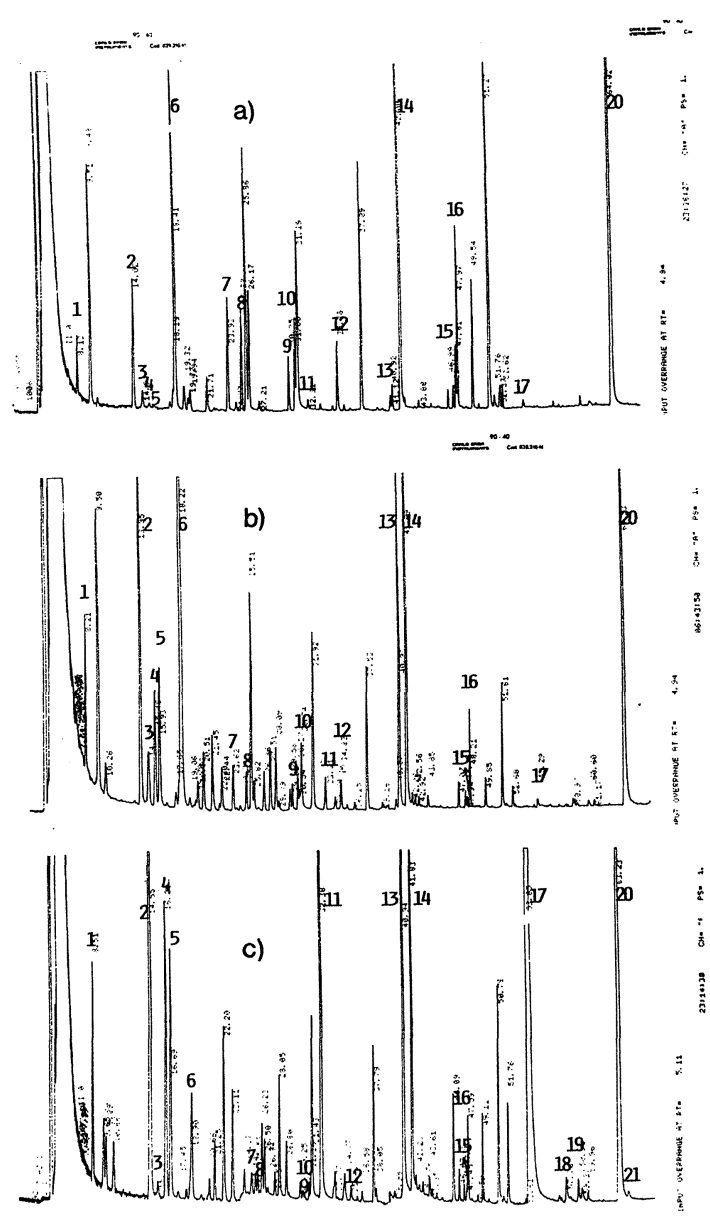

Figure 2

Aroma HRGC analysis of the oils obtained from olives at different times of storage. a) from just harvested olives; b) from olives stored for four days; $c$ ) from olives stored for eight days. Peaks: $n .1=n$-octan; $n .2=$ ethyl acetate; $n .3=$ methanol; $n .4=$ 2-methyl butan-1-al; n.5=3-methyl butan-1-al; n.6= ethanol; n. $7=\mathrm{C}_{10} \mathrm{H}_{18} ; \mathrm{n} .8=\mathrm{C}_{10} \mathrm{H}_{18} ; \mathrm{n} .9=$ not identified compound;

n. $10=\mathrm{C}_{10} \mathrm{H}_{18} ; \mathrm{n} .11=2$-methyl propan-1-ol; n.12= not identified compound; $n$.13=2-methyl butan-1-ol+3-methyl butan-1-ol; n. 14= trans-2-hexen-1-al; n.15= cis-3-hexen-1-ol acetate; $n \cdot 16=$ trans-2-penten-1-ol; n.17= acetic acid; $n \cdot 18=$ propionic acid; n. 19=2-methyl propionic acid; $n .20=1$-nonanol (internal standard); n.21= $3=$ methyl butanoic acid. 
Among numerous peaks present in the aromagram only those that indicated well defined trends in relation to the increasing intensity of fusty were considered. Table II showed their contents expressed in $\mathrm{mg}$ of 1 nonanol per $\mathrm{kg}$ of oil.

Some of these compounds, occurring in considerable quantities in oils extracted from fresh and healthy olives, rapidly decreased; in particular trans-2-hexenal, with own pleasant aroma of grass just cut, that represented the $34 \%$ of total aroma of oil obtained from olives crushed just after harvest, cis-3hexen-1-ol acetate and some $\mathrm{C}_{10} \mathrm{H}_{18}$ hydrocarbons with terpenic structures (12), presumably isomers because they showed identical mass spectra (Camera, unpublished data). Cis-3-hexen-1-ol acetate and $\mathrm{C}_{10} \mathrm{H}_{18}$ hydrocarbons are related to «green" notes of aroma of which they represent about $11 \%$ in the reference sample.
In the long run, all compounds linked to the quality characteristics of oils progressively decreased and thus contributed in always lower proportions to the flavour of resulting oils (Table III); that caused a notable flattening of fruity, regularly perceived by tasters (Table I).

At the same time the total aroma of oils obtained from olives stored for different times showed a sharp increase (Table III). It was related to the accumulation of metabolites produced by microorganisms involved in the storage of fruits. The presence of these compounds had as a consequence distortion of flavour and appearance and intensifying of fusty defect.

The evolution of microflora occurring on the olive surface in the course of storage in piles, was summarized in Figure 3. At harvest there were mainly lactic acid bacteria, yeasts, moulds and

Table II

Volatile metabolites (as ppm of 1-nonanol) produced during olive storage

\begin{tabular}{lrrrrr}
\hline Compounds/Storage days & \multicolumn{1}{c}{0} & \multicolumn{1}{c}{2} & \multicolumn{1}{c}{4} & \multicolumn{1}{c}{6} & \multicolumn{1}{c}{8} \\
\hline$n$-octan & 2.6 & 4.6 & 9.6 & 10.3 & 11.3 \\
ethyl acetate & 8.9 & 23.2 & 47.0 & 71.4 & 139.9 \\
methanol & 1.1 & 2.2 & 8.1 & 6.3 & 1.1 \\
2-methyl butan-1-al & 0.2 & 2.2 & 13.5 & 20.6 & 28.6 \\
3-methyl butan-1-al & 0.2 & 3.0 & 16.5 & 19.6 & 23.6 \\
ethanol & 30.9 & 125.9 & 163.8 & 116.1 & 11.8 \\
$\mathrm{C}_{10} \mathrm{H}_{18}$ & 8.6 & 6.0 & 4.7 & 2.7 & 1.8 \\
$\mathrm{C}_{10} \mathrm{H}_{18}$ & 7.3 & 5.3 & 3.7 & 1.9 & 1.3 \\
not identified compound & 3.4 & 2.2 & 1.9 & 1.2 & 0.5 \\
$\mathrm{C}_{10} \mathrm{H}_{18}$ & 5.6 & 4.9 & 2.8 & 2.1 & 1.1 \\
2-methyl propan-1-ol & 0.6 & 4.5 & 16.5 & 43.6 & 67.1 \\
not identified compound & 4.2 & 2.9 & 2.4 & 1.7 & 0.9 \\
2-methyl butan-1-ol+3-methyl butan-1-ol & 1.5 & 17.6 & 37.0 & 59.0 & 77.9 \\
trans-2-hexen-1-al & 101.6 & 88.6 & 80.0 & 65.6 & 46.6 \\
cis-3-hexen-1-ol acetate & 2.8 & 1.1 & 0.8 & 0.7 & 0.7 \\
trans-2-penten-1-ol & 9.3 & 7.3 & 7.2 & 5.8 & 5.0 \\
acetic acid & 0.2 & 0.2 & 0.6 & 26.5 & 1059.2 \\
propionic acid & - & - & $\mathrm{tr}$ & 0.9 & 1.6 \\
2-methyl propionic acid & - & - & $\mathrm{tr}$ & 0.3 & 0.5 \\
3-methyl butanoic acid & - & - & $\mathrm{tr}$ & $\mathrm{tr}$ & 0.7 \\
\hline
\end{tabular}

Table III

Changes of contents (as ppm of 1-nonanol) of total aroma and compounds related to oil quality during olive storage

\begin{tabular}{lrrrrr}
\hline & \multicolumn{5}{c}{ Storage days } \\
\cline { 2 - 6 } & \multicolumn{1}{c}{0} & \multicolumn{1}{c}{. } & \multicolumn{1}{c}{4} & 6 & 8 \\
\hline total aroma & 296.8 & 473.2 & 567.3 & 632.7 & 1622.8 \\
trans-2-hexen-1-al & 101.6 & 88.6 & 80.0 & 65.6 & 46.6 \\
cis-3-hexen-1-ol acetate $+\mathrm{C}_{10} \mathrm{H}_{18}$ & 31.4 & 20.6 & 18.2 & 10.7 & 7.6 \\
\hline
\end{tabular}




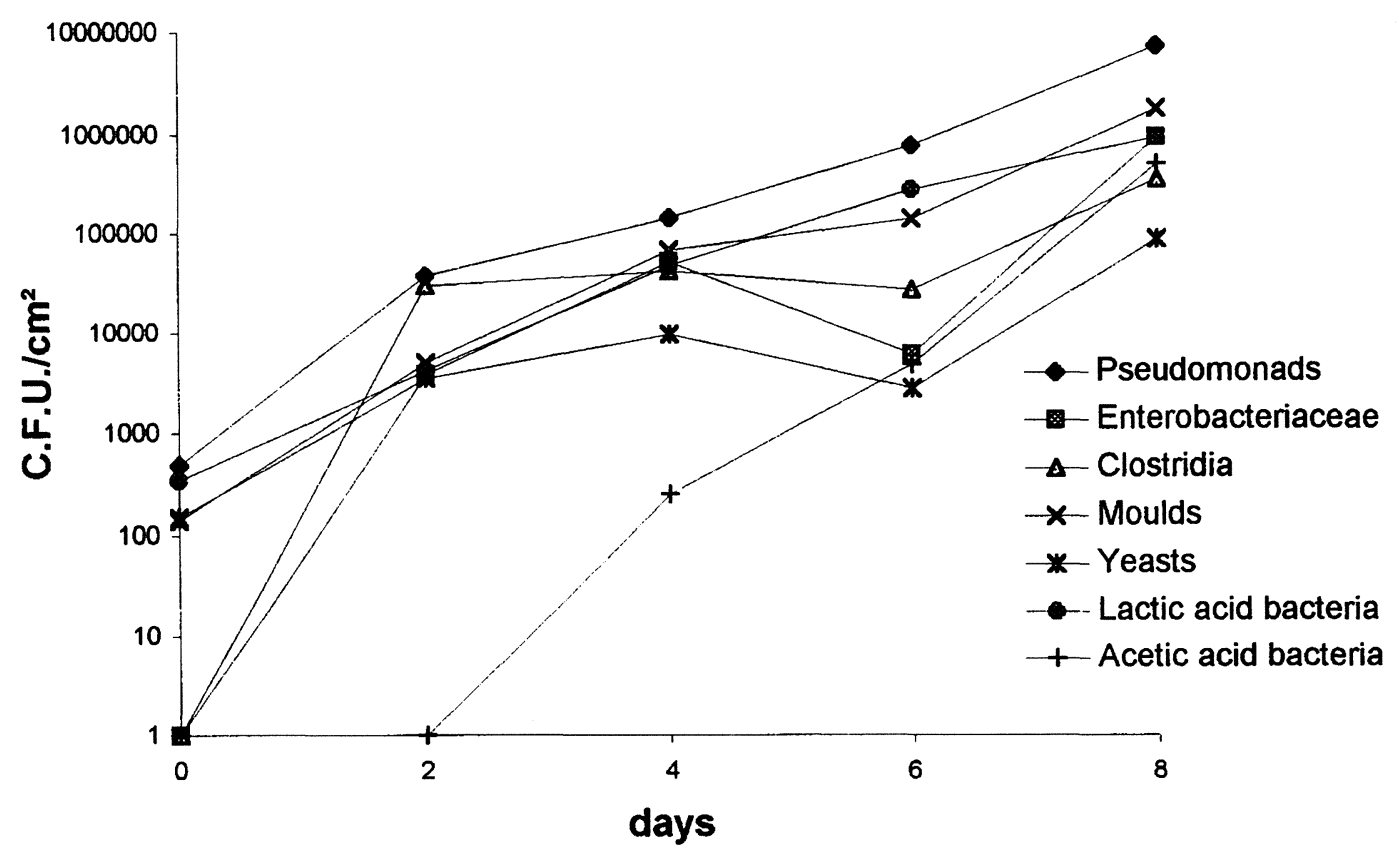

Figure 3

Logarithmic trends of microorganisms involved in olive storage

pseudomonads, usual components of the epiphytic microflora; after two days of preservation some microorganisms that could be attributed to Enterobacter and Clostridium genera, absent or almost on the fresh olives, showed a rapid development getting colonies forming units per $\mathrm{cm}^{2}$ of olive surface (C.F.U./cm²) to $10^{3}$ and $10^{4}$ respectively which remained quite constant in the subsequent steps of storage.

Some oil volatile compounds, as 2-methyl butan-1al, 3-methyl butan-1-al, 2-methyl propan-1-ol, 3methyl butan-1-ol, propionic acid, 2-methyl propionic acid and 3-methyl butanoic acid, are form intermediates of very well known pathway of conversion of valine (Fig. 4), leucine (Fig. 5a) and isoleucine (Fig. 5b) aminoacids. Identified species of $P$ seudomonas genus, as $P$. aeruginosa, $P$. putida and $P$. fluorescens, in continuous growth during the preservation of the olives, use valine (18) as carbon source and therefore may produce 2-methyl propan1-ol, 2-methyl propan-1-al, propionic acid and 2methyl propionic acid; besides the enzymatic conversion of valine, leucine and iso-leucine could be carried out by species belonging to Clostridium genus $(18,19)$ which, present in few specimens on the fresh sample, showed a dramatic increase in the first two days of preservation (Fig. 3). Although the production of metabolites arising from conversion of cited aminoacids, in trace in the oil obtained from fresh olives, showed a relevant increase as from two days of storage (Table II), the fusty defect was perceived only after 4 days when these metabolites had higher concentration.
The identification of species belonging to Enterobacter allowed to establish that almost all of them had to be attributed to $E$. agglomerans, a microorganism which invades plant tissues causing softening and rot, since it has in its enzymatic store pectinolytic enzymes (18). The intervention of these enzymes and those of the moulds could be the cause of the rigid spatial structure destruction of the pectic substances (20) present in the cuticle (Fig. 6a), and in the middle lamella among cell walls (Fig. 6b). The loss of olive pulp texture was usually observed to the touch as from the starting days of drupe storage.

The observations by SEM of tissue evidenced the thickness reduction of the cuticle from $32.4 \mu \mathrm{m}$ to 25.5 $\mu \mathrm{m}$ (Fig. 7) and the progressive disappearance of middle lamella (Fig. 8); the impoverishment of pectic substances from last tissue made less effective their adhesive action on the cellulosic cell walls giving rise to unsticking of mesocarp cells and, consequently, softening and loss of pulp texture (21-23), well evidenced after only four days of olive storage (Fig. $8 c)$. Pectic compound degradation was proved by the increase of methanol content (Table II), in its turn probably used as carbon source by other microorganisms. Furthemore, the destruction of cellulosic wall of mesocarp cells was also evidenced: it is proved by the deep lacerations pointed out by SEM (Fig 8c-e) on olive pulp blocks, probably ascribable to the action of cellulosolytic enzymes contained into some species of Clostridium (18). 


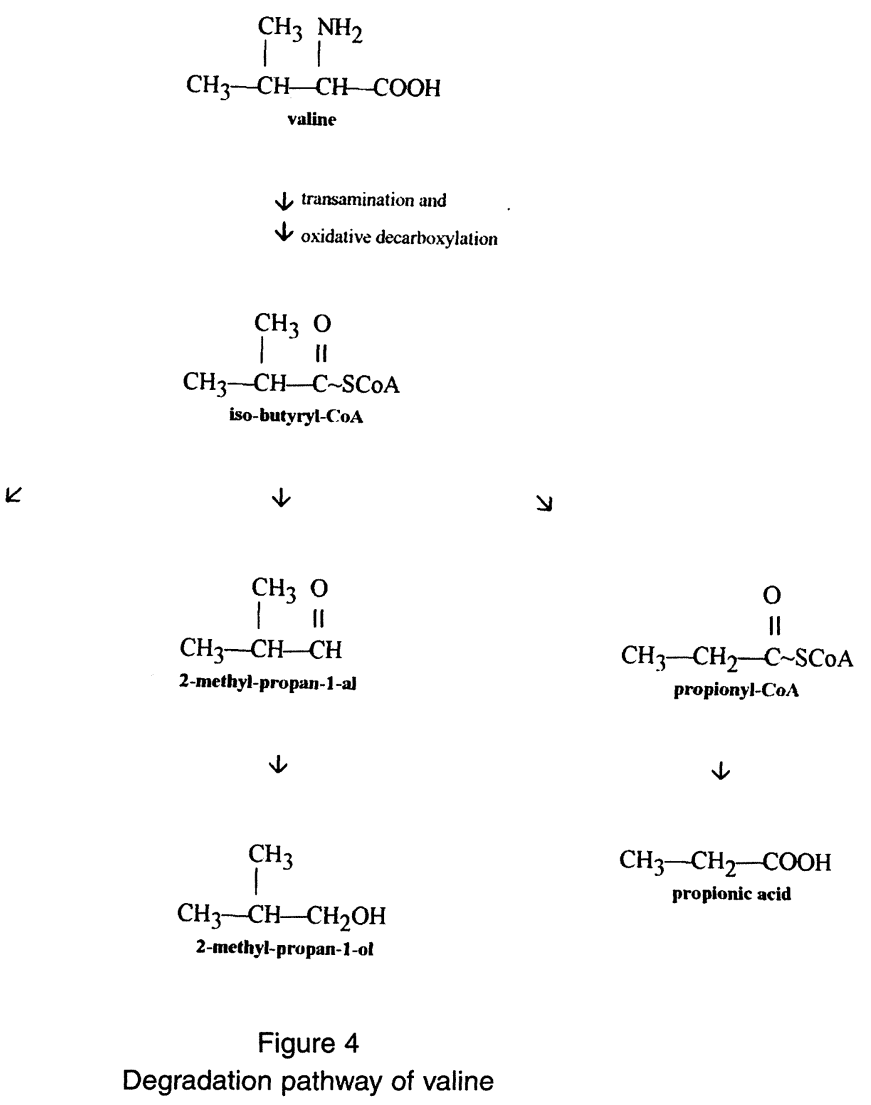

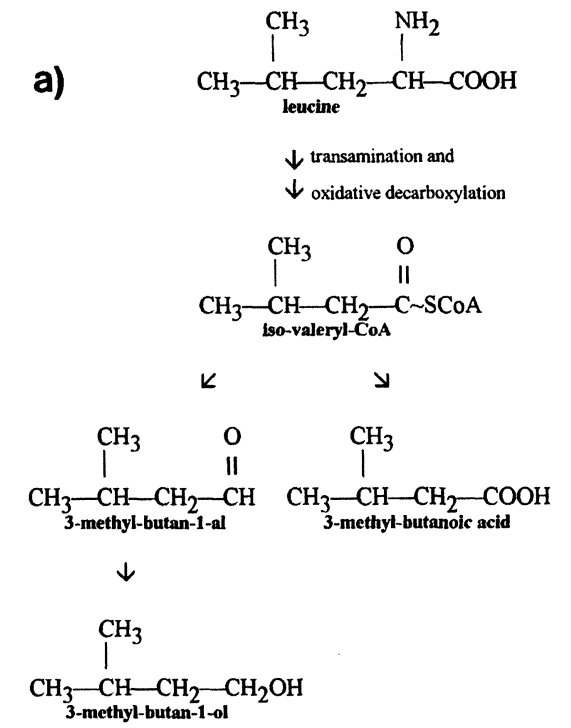

b)

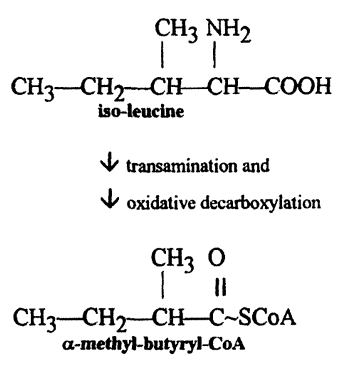

$\downarrow$

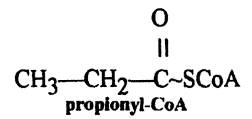

$\downarrow$

$\mathrm{CH}_{3}-\mathrm{CH}_{2}-\mathrm{COOH}$

Figure 5

Degradation pathways of leucine (a) and iso-leucine (b) 
a)
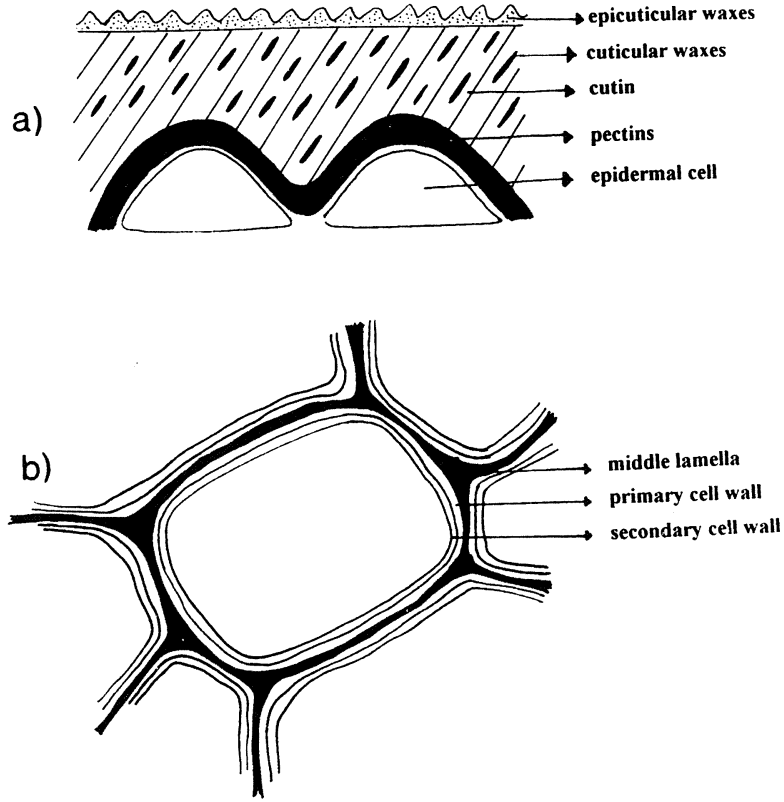

Figure 6

Schematic representation of cuticle layer (a) and cell walls (b) of olive fruit

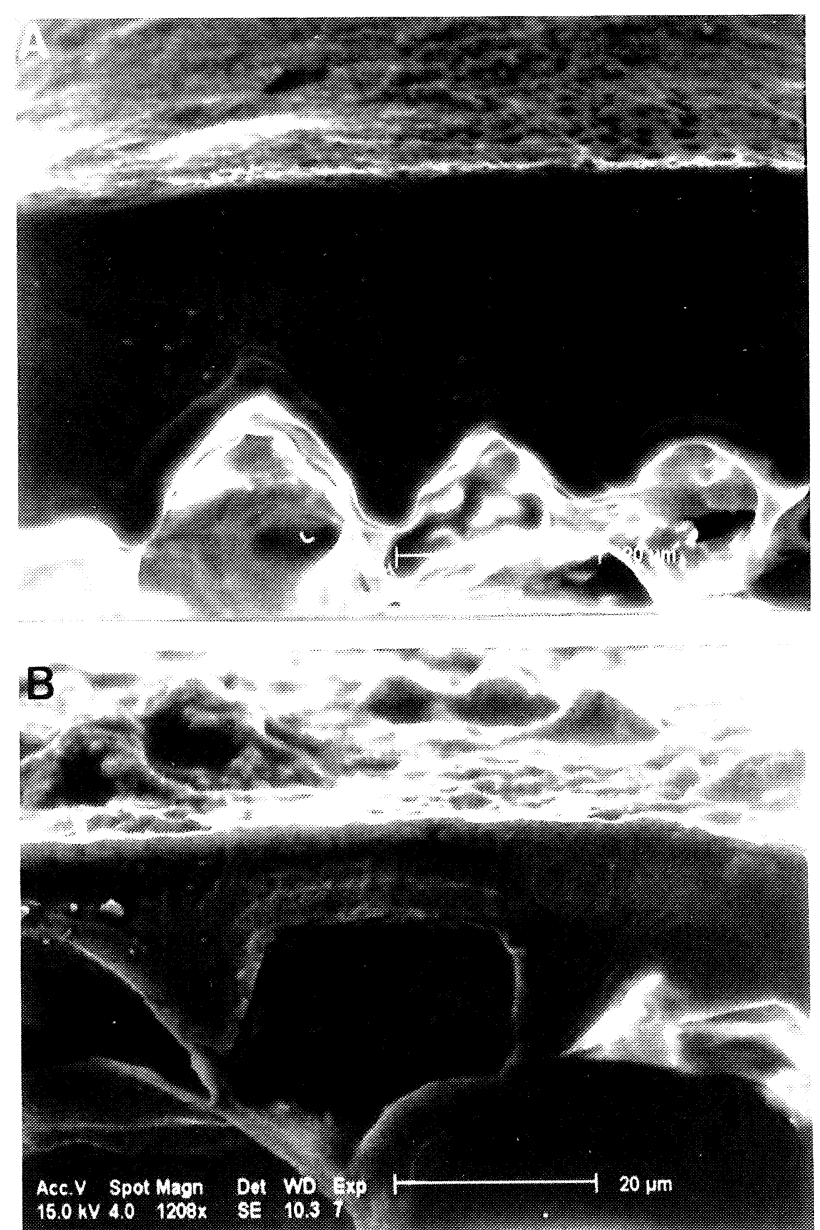

Figure 7

Reduction of cuticle thickness during storage. a) just harvested olives; b) olives after eight days of storage
Among the epiphytic microflora, lactic acid bacteria, identified as Lactobacillus plantarum, $L$. brevis, $L$. fermentum, and yeasts had to be considered; they ferment simple sugars producing lactic acid and ethanol respectively. At the examination of volatile metabolites, ethanol showed a considerable increase in relation to the growth of yeasts in the starting samples (from 0 to 4 storage days) (Table II). After six days, ethanol content suffered a sudden decrease and, at the same time, a noticeable development of acetic acid bacteria (Fig. 3 ), ascribable to Acetobacter genus, was observed.
These microorganisms grow as secondary microflora in the roting, substratum making the oxidation of ethanol to acetic acid; whilst, a dramatic increase of acetic acid, perceived by tasters as vinegary defect, was recorded.

Finally it must be specified that the continuos acidification of substratum, made by lactic and acetic acid bacteria, temperature and high humidity considerably encouraged the mould development (Fig. 3), that further modified the characteristics of oil flavour, causing the appearance of musty defect, perceived by Panel tasters. 

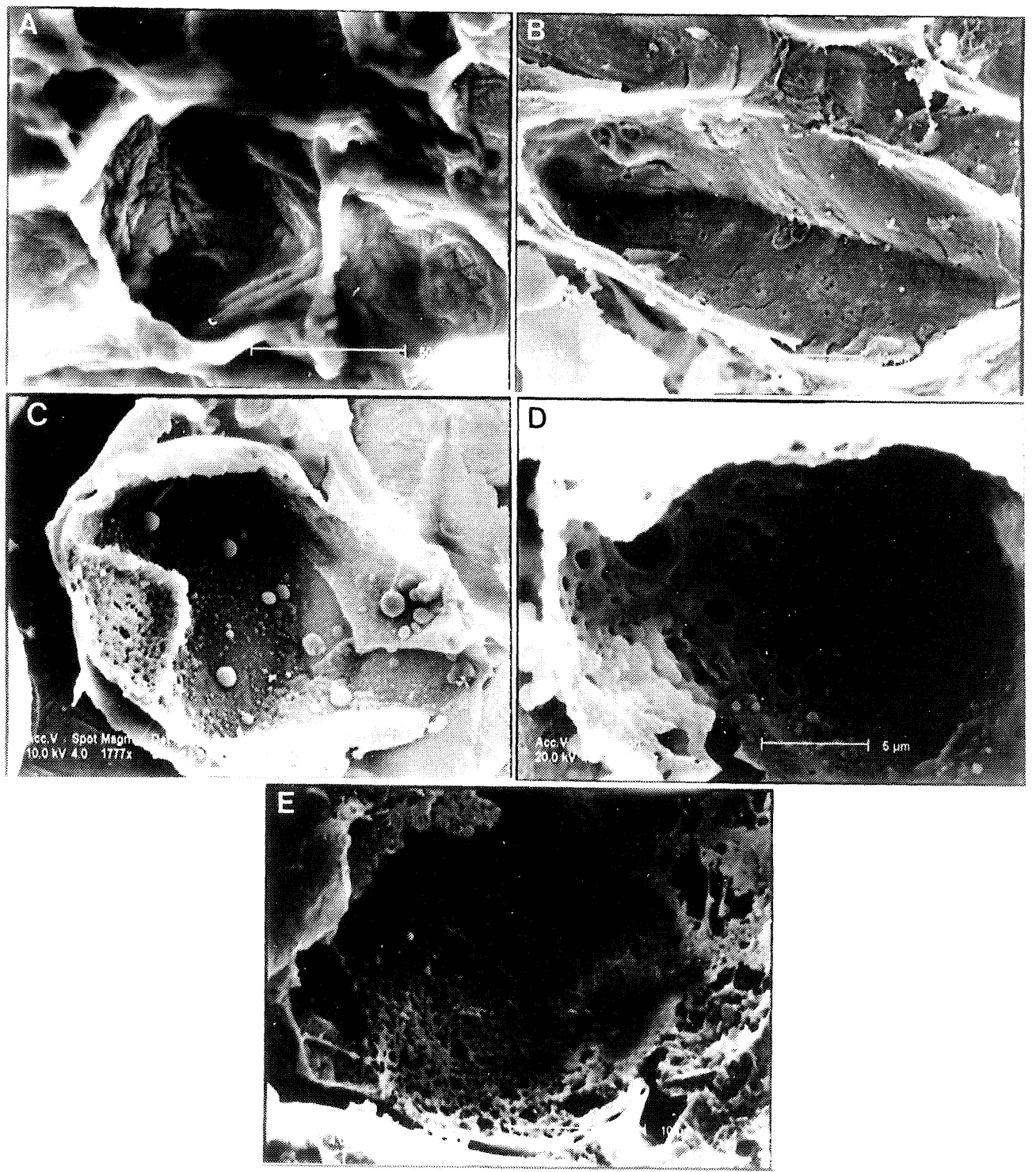

Figure 8

Evolution of mesocarp during storage: mesocarpic cells of just harvested olives (a), after two days (b), after four days (c), after six days (d) and after eight days (e) of storage

\section{ACKNOWLEDGEMENTS}

The Authors acknowledge M. Javier Tardaguila Laso for helpful comments. The Italian Ministero delle Risorse Agricole, Alimentari e Forestali is thanked for financial support.

\section{REFERENCES}

1. Olias, J. M., Gutiérrez Rosales, F. and Dobarganes García, C. (1980). - «Componentes volátiles en el aroma del aceite de oliva. IV. Su evolución e influencia en el aroma durante el proceso de maduración de los frutos en las variedades Picual y Hojiblanca».- Grasas y Aceites 31, 391-402.

2. Bertuccioli, M., Anichini, F. and Montedoro, G. (1978) - «Maturaziorie delle olive e qualità dell'olio: costituenti volatili dello spazio di testa».- Tecnol. Alim., mar/apr 97.

3. Solinas, M., Marsilio, V. and Angerosa, F. (1987) -«Evoluzione di alcuni componenti dell'aroma degli oli vergini di oliva in relazione al grado di maturazione delle olive".- Riv. It. Sost. Grasse 64, 475-480.

4. Solinas, M., Angerosa, F. and Marsilio, V. (1988). - «Indagine su alcuni componenti dell'aroma degli oli vergini di oliva in relazione alla varietà».- Riv. It. Sost. Grasse 65, 361-368.

5. Montedoro, G. and Garofalo, L. (1984). - «Caratteristiche qualitative degli oli vergini di oliva. Influenza di alcune variabili: varietà, ambiente, conservazione, estrazione, 
condizionamento del prodotto finito".- Riv. It. Sost. Grasse 61, 157-168.

6. Montedoro, G. (1992). - «l fattori tecnologici responsabili della qualità degli oli vergini di oliva».- Uliveto 20, 6-11.

7. Di Giovacchino, L., Mascolo, A., Solinas, M. and Angerosa, F. (1980). - «Incidenza dei sistemi di lavorazione delle olive su alcuni parametri indicativi della qualità dell'olio d'oliva".- In: Proceedings of 3th International Congress "Biological value of olive oil», 812 September, Chania, Creta.

8. Angerosa, F. and Solinas, M. (1990). - «nfluenza della frangitura sulle caratteristiche di qualità dell'olio di oliva". - In: Proceedings of International Seminar "Olive oil and table olives: technology and quality", 25-28 April, Città S. Angelo (PE), Italy.

9. Angerosa, F. and Di Giacinto, L. (1995). - «Caratteristiche di qualità dell'olio di oliva vergine in relazione ai metodi di frangitura. Nota II».- Riv. It. Sost. Grasse 72, 1-4.

10. Di Giovacchino, L. (1991). - «L'estrazione dell'olio con la centrifugazione diretta delle paste di olive. Nota I: influenza della gramolazione».- Riv. It. Sost. Grasse 68, 413-420.

11. Angerosa, F., Solinas, M. and Di Giacinto, L. (1989). - «nfluence du stockage des olives sur la flaveur de I'huile".- In: Proocedings of "Chevreul" International Congress, 6-9 June, Angers, France, pp. 571-577.

12. Gutiérrez, R., Dobarganes, M. C., Gutiérrez, F. and Olias, J. M. (1981). - «Componentes volátiles en el aroma del aceite de oliva virgen. V. Aceites obtenidos de frutos atrojados".- Grasas y Aceites 32, 299-303.

13. Angerosa, F., Di Giacinto, L. and Solinas, M. (1990). - «Influenza dello stoccaggio in massa delle olive sull'aroma degli oli di risulta: valutazione del difetto di "riscaldo" mediante analisi HPLC e GLC dei componenti volatili».Riv. Merceol. 29, 275-294.

14. EC Regulation n. 2568 of 11 July 1991.

15. Bergey's Manual of Determinative Bacteriology.Buchanan R.E. and Gibbons N.E. (Eds.).- The Williams \& Wilkins Company, Baltimore.

16. Hatanaka, A., Kajiwara, T. and Sekiya, J. (1987). - «Biosynthetic pathway for C6-aldehydes formation from linolenic acid in green leaves".- Chem. Phys. Lipids 44, 341-361.

17. Di Giovacchino. L., Angerosa, F. and Di Giacinto L. (1995). - «Effect of mixing leaves with olives on quality of oil obtained by centrifugation".- J. Am. Oil Chem. Soc., in press.

18. Griffith, O. W., (1986). «b-amino acids: mammalian metabolism and utility as a-amino acid analogues".Ann. Rev. Biochem. 55, 855-878.

19. Handbook of microbiology.- Laskin A.I. and Lechevalier H. A. (Eds.).-CRC Press, Cleveland (Ohio).

20. Castillo Gómez, J., Mínguez Mosquera, M. I. and Fernández Díez, M. J. (1974). -«Enzimas pectinolíticas y su relación con el ablandamiento de los productos del aderezo". Grasas y Aceites 25, 362-366.

21. Fernández Díez, M. J., and Mínguez Mosquera, M. I. (1973). - «Las substancias pécticas y su relación con la textura de producto del aderezo".- Grasas y Aceites 24, 29-36.

22. Marsilio, V., Solinas, M. and Vlahov, G. (1984-87). - "Correlazione tra costituenti pectici e consistenza della polpa delle olive. Nota 2. Influenza del processo di trasformazione".- Ann. Ist. Sper. Elaiot., $X$.

23. Marsilio, V. and Solinas, M. (1990). -«Presenza e comportamento delle sostanze pectiche nelle olive da tavola. Influenza della varieta' e della tecnologia».- In: Proceedings of International Seminar "Olive oil and table olives: technology and quality", 25-28 April, Città S. Angelo (PE), Italy, pp. 275-290. 